\title{
Aflatoxin contamination of maize in Thailand 2. Aflatoxin contamination of maize harvested in the rainy seasons of 1984 and 1985
}

\author{
T. Goto*1, S. KaWASUGI*2, O. TSURUTA*1, H. OKaZAKI*1, \\ P. SiRIACHA ${ }^{* 3}$, D. BUANGSUWON ${ }^{* 8}$, and M. MANABE*1 \\ 後藤 哲久*1, 川杉 正一², 鶴田 理*1, 岡崎 博*1, Prisnar SIRIACHA ${ }^{* 3}$, \\ Dara BUANGSUWON*8, 真鍋 勝*1: タイ国産メイズのアフラトキシン污染 \\ 2. 1984, 1985年雨期産メイズのアフラトキシン污染
}

\begin{abstract}
Summary
The amounts of aflatoxins in maize collected from various points ranging from field to silo during the rainy season of 1984 and 1985 were measured. In 1985, the aflatoxin contamination at fields and farm storages was infequent and low in levels. However, maize samples collected from either middleman's storages or silos in 1984 and 1985 were highly contaminated with aflatoxins. The highest amounts of aflatoxin $\mathrm{B}_{1}$ detected from samples were 1310 and $767 \mathrm{ppb}$ in 1984 and 1985, respectively. These results clearly showed that most of the aflatoxin contamination on the maize occurred after harvest, especially during the period of storage at the middleman's place.
\end{abstract}

Maize is widely planted throughout the tropics and temperate zones. Most of these areas are suitable for the growth of aflatoxin-producing fungi ${ }^{1{ }^{1}}$ such as Aspergillus flavus and $A$. parasiticus. For this reason, maize is often contaminated with aflatoxins ${ }^{2)}$. Payne ${ }^{3)}$ reviewed that, in the U.S.A., aflatoxin contamination in maize occurred mainly in the field. Lillehoj et al. ${ }^{4}$ also reported the natural occurrences of aflatoxins in maize in the field. However, a recent report $\mathrm{t}^{5}$ ) showed that, in Thailand, aflatoxin contamination in maize occurred after harvest. There are possibly some differences between the factors affecting aflatoxin production in the U.S.A. and those in Thailand, based on the different agricultural conditions such as climates, cultivar of maize, cropping season and economic situation of farmers. Therefore, in 1984 and 1985, several maize samples were collected from various points ranging from the fields to port silos throughout the maize-production areas in central Thailand and the extents of aflatoxin contamination were determined.

*1 National Food Research Institute (Tsukuba, Ibaraki 305)

農林水産省食品総合研究所（干305 茨城県筑波郡谷田部町観音台2-1-2）

*2 Tropical Agriculture Research Center (Tsukuba, Ibaraki 305)

農林水産省熱帯農業研究センター（テ305 茨城県筑波郡谷田部町大わし1-2）

*3 Plant Pathology and Microbiology Division, Department of Agriculture (Bangkhen, Bangkok, Thailand)

タイ農業局植物病理・微生物部（タイ国バンコク市バンケン） 


\section{Materials and Methods}

Samples: Maize samples were collected from the fields, farm storages, the middleman's storages and drying facilities and port silos, either in September of 1984 or from August to October of 1985. These were from the maize-production areas in Thailand from Lop Buri to Loei including the areas of Nakhon Ratchasima, Phetchabun, Phitsanulok and Nakhon Sawan. Some samples were also collected from port silos in Bangkok. Sixtythree samples collected as bulk from bag or pile of maize were dried and stored under $-20^{\circ} \mathrm{C}$ before aflatoxin analysis. Five hundred grams of each sample was used for the analysis. Apart from the bulk samples, 30 maize ears were individually collected from 3 different farm storages (10 ears from each storage), and 20 ears were collected either from silo or middleman's storages. These ear samples were shelled and analyzed individually.

Extraction, purification and analysis of aflatoxins: Each maize sample was milled to the size passed through $1 \mathrm{~mm}$ mesh by an ultra centrifuge mill (ZM-1, Retsch, W. Germany). The ground samples were extracted with chloroform and then purified using alumina-silica gel columns ${ }^{6}$.

The purified samples were applied on silica gel TLC plates (Merck 5721) and developed in half-lined chambers using toluene:ethyl acetate:methanol:90\% formic acid (60:30:5:10, $\mathrm{v} / \mathrm{v} / \mathrm{v} / \mathrm{v}$ ) as the mobile phase. All samples containing aflatoxins or aflatoxin-like fluorescent compounds were analyzed by high-performance liquid chromatography ${ }^{7}$. The system of liquid chromatograph and conditions of analysis were same as previously reported ${ }^{8}$.

Aflatoxin standards were purchased from Makor Chem. Co. (Israel), and TLC plates, silica gel and alumina were purchased from E. Merck (W. Germany). All other chemicals were GR grade.

\section{Results and Discussion}

As shown in Tables 1 and 2, bulk samples from either the fields or farm storages were contaminated with aflatoxins at very low levels and infrequently. From the individual analysis of ear samples, only three ears were positive for aflatoxin contamination and the levels of aflatoxin $B_{1}$ were $0.3 \mathrm{ppb}$, trace, and $0.3 \mathrm{ppb}$ (Table 3). These results confirmed that the aflatoxin contamination of maize was low in the fields and farm storages.

In contrast to the farm, bulk samples collected from the middlemen or silos were highly contaminated with aflatoxins. As shown in Table 1 , over $85 \%$ and over $80 \%$ of the bulk samples were contaminated with aflatoxins in 1984 and 1985 respectively, and the ranges of aflatoxin $B_{1}$ concentrations in the positive samples were 6.3 to $1310 \mathrm{ppb}$ and 0.6 to $767 \mathrm{ppb}$ in 1984 and 1985. As shown in Table 3, there were 5 aflatoxin positive ears collected from middleman's storages or silo with the concentration of aflatoxin $B_{1}$ varying from 2.3 to $2960 \mathrm{ppb}$. In the case of the ear samples, the frequency of aflatoxin contamination was lower than that of the bulk samples but some of the ears contained very high amounts of aflatoxin $B_{1}$. 
Table 1. Summarized results on aflatoxin contamination in maize (bulk samples)

\begin{tabular}{lccccc}
\hline Sample from & $\begin{array}{c}\text { No. of } \\
\text { samples } \\
\text { analyzed }\end{array}$ & $\begin{array}{c}\text { Aflatoxin } \\
\text { detected }\end{array}$ & $\begin{array}{c}\text { Average } \\
\text { aflatoxins } \\
\text { in all analyzed } \\
\text { samples }\end{array}$ & $\begin{array}{c}\text { No. of } \\
\text { aflatoxin } \\
\text { positive } \\
\text { samples }\end{array}$ & $\begin{array}{c}\text { Range of } \\
\text { aflatoxins } \\
\text { in positive } \\
\text { samples }\end{array}$ \\
\hline Fislu ${ }^{* !}$ & 22 & $\mathrm{~B}_{1}$ & $3.1 \mathrm{ppb}$ & 3 & $5.8-51.7 \mathrm{ppb}$ \\
Merchant $84^{* 2}$ & 14 & $\mathrm{~B}_{2}$ & 0.5 & 2 & $0.4-6.9$ \\
Merchant $85^{* 3}$ & 27 & $\mathrm{~B}_{1}^{* 4}$ & 177 & 12 & $6.3-1310$ \\
& & $\mathrm{~B}_{1}$ & 166 & 22 & $0.6-767$ \\
& $\mathrm{~B}_{2}$ & 13.2 & 21 & trace*5-50.4 \\
& & $\mathrm{G}_{1}$ & 0.7 & 6 & trace-11.5 \\
& $\mathrm{G}_{2}$ & 0.05 & 3 & trace \\
\hline
\end{tabular}

*1 Collected from the fields and farm storages in 1985.

*2 Collected from middlemen or silos in 1984.

*3 Collected from middlemen in 1985.

*4 Only aflatoxin $\mathrm{B}_{1}$ was analyzed.

*5 Less than $0.5 \mathrm{ppb}$.

Table 2. Distribution of aflatoxin $\mathrm{B}_{\mathbf{1}}$ contamination in maize (bulk samples)

\begin{tabular}{lcccccc}
\hline Sample from & $\begin{array}{c}\text { No. of } \\
\text { sample } \\
\text { analyzed }\end{array}$ & \multicolumn{2}{c}{ Number of samples containing aflatoxin $B_{1}$ in the stated range (ppb) } \\
\cline { 3 - 8 } & 22 & 14 & 2 & 1 & $101-500$ & $>501$ \\
\hline Field & & 2 & 4 & 2 & 0 & 0 \\
Merchant $84^{* 2}$ & 14 & 5 & 6 & 2 & 5 & 1 \\
Merchant $85^{* 3}$ & 27 & & &
\end{tabular}

${ }^{* 1-3}$. See footnotes in Table 1 .

Table 3. Summarized results on aflatoxin $B_{1}$ contamination in maize (ear samples)

\begin{tabular}{|c|c|c|c|}
\hline Sample from & $\begin{array}{l}\text { No. of samples } \\
\text { analyzed }\end{array}$ & $\begin{array}{l}\text { No. of aflatoxin } \\
\text { positive samples }\end{array}$ & Amounts of aflatoxin $\mathrm{B}_{1}$ \\
\hline Farm A & 10 & 0 & \\
\hline Farm B & 10 & 2 & trace $^{* 1}, \quad 0.3$ \\
\hline Farm C & 10 & 1 & 0.3 \\
\hline Middleman A & 5 & 2 & $2.3, \quad 8.7$ \\
\hline Middleman B & 6 & 2 & $424, \quad 2960$ \\
\hline Port silo & 9 & 1 & 310 \\
\hline
\end{tabular}

*1 Less than $0.2 \mathrm{ppb}$.

Aflatoxin $B_{2}$ was detected from most of the aflatoxin $B_{1}$ positive samples, and aflatoxins $G_{1}$ and $G_{2}$ were also detected from some of them (Table 1). In most of the case, the concentrations of aflatoxin $B_{2}$ were around $10 \%$ of those of aflatoxin $B_{1}$, and the levels of aflatoxins $G_{1}$ and $G_{2}$ were lower than those of aflatoxin $B_{2}$.

These data show that, in Thailand, most of the aflatoxin contamination in maize occurred after harvest, especially during stock at the merchant. This indicates that aflatoxin contamination of maize most likely occurs after being shelled usually by the middleman. Some physical damages on the shelled kernels facilitate the infection with aflatoxin-producing fungi and the subsequent production of aflatoxins during drying and storage. Thus 
the improvement of postharvest handling of maize, especially during shelling and drying, should be necessary to control the aflatoxin contamination in Thailand.

\section{Acknowledgments}

The authors thank Mr. P. Tanboon-ek, Mr. K. Tanaka and Mr. M. Saito for their various assistances for this research, Mr. S. Kositeharoenkul, Ms. P. Limpisavat, Ms. Y. Nathongpoon, Ms. K. Panawat and Ms. N. Paramacom for their technical assistance, Mr. A. Tongdee, Mr. V. Kajornmalee, Chao Phya Co., Ltd., Overseas Merchandise Inspection Co., Ltd. and Bangkok Bank for their kindly help for sampling and also Ms. Linda Beltran for her reviewing assistance.

\section{References}

1) Manabe, M., Tsuruta, O., Goto, T., Matsuura, S.: Report. Natl. Food Res. Inst., 33, 49 (1978).

2) Stoloff, L.: "Carcinogens and Mutagens in the Environment. Vol. 1, Food Products" p. 97 (1982), CRC Press, FL.

3) Payne, G.A.: "Aflatoxin and Aspergillus flavus in Corn" p. 16 (1983), Auburn University Alabama.

4) Lillehoj, E. B., Kwolek, W. F., Shannon, G. M., Shotwell, O. L., Hesseltine, G. W.: Cereal Chem., 52, 603 (1975).

5) Asanuma, K., Vayuparu, S.: Proc. Jpn. Assoc. Mycotoxicol., 21, 17 (1985).

6) Goto, T., Manabe, M., Matsuura, S.: Agric. Biol. Chem., 43, 2591 (1979).

7) Manabe, M., Goto, T., Matsuura, S.: Agric. Biol. Chem., 42, 2003 (1978).

8) Goto, T., Kawasugi, S., Tsuruta, O., Siriacha, P., Buangsuwon, D., Sriboonruang, C., Manabe, M.: Proc. Jpn. Assoc. Mycotoxicol., 24, 47 (1986). 